\title{
Advanced maternal age and factors associated with neonatal near miss in nulliparous and multiparous women
}

\author{
Idade materna avançada e fatores associados \\ com o near miss neonatal em mulheres \\ nulíparas e multíparas
}

\section{Edad avanzada en la maternidad y factores asociados a la casi pérdida/near miss neonatal en mujeres nulíparas y multíparas}

Katrini Guidolini Martinelli 1,2

Silvana Granado Nogueira da Gama 2 André Henrique do Vale de Almeida 2

Vanessa Eufrauzino Pacheco 2

Edson Theodoro dos Santos Neto 1

\begin{abstract}
The early neonatal period accounts for approximately half of the deaths of young children under one year of age, and the neonatal near miss can recognize factors causing this high number of deaths. Thus, the aim of this study is to determine whether advanced maternal age increases the chance of neonatal near miss, in addition is to identify which factors are associated with the neonatal near miss, stratified by parity. Data are from the 2011-2012 Birth in Brazil study, which used a national population-based sample of 15,092 newborns of women between 20-29 and 35 years of age or more (advanced maternal age). Multiple logistic regression was performed to test the association between neonatal near miss and prenatal and childbirth variables, pregestational diseases, obstetric history and socioeconomic characteristics, stratified by parity. Advanced maternal age was to be statistically associated with neonatal near miss in nulliparous $(O R=1.62$; 95\%CI: 1.05-2.50) and multiparous $(O R=1.51 ; 95 \% C I: 1.20-1.91)$ when compared to women $20-29$ years of age. For nulliparous women, the main variables statistically associated with neonatal near miss were multiple gestation $(O R=8.91)$ and hypertensive disease $(O R=2.57)$, whereas forceps-assisted vaginal delivery $(O R=7.19)$ and multiple gestation $(O R=4.47)$ were the variables associated for multiparous women. Neonatal near miss has been shown to be connected with access to health services for childbirth, gestational complications and maternal characteristics, mainly advanced maternal age. Therefore, to properly monitor and classify maternal gestational risk, to control gestational complications during prenatal care, and to correctly refer these women to childbirth care should be priority strategies for healthcare services.
\end{abstract}

Early Neonatal Mortality; Maternal Age; Healthcare Near Miss; Prenatal Care
Correspondence

K. G. Martinelli

Centro de Ciências da Saúde, Universidade Federal do Espírito Santo.

Av. Marechal Campos 1468, Vitória, ES 29043-260, Brasil. katrigm@gmail.com

\footnotetext{
1 Universidade Federal do Espirito Santo, Vitória, Brasil. 2 Escola Nacional de Saúde Pública Sergio Arouca, Fundação Oswaldo Cruz, Rio de Janeiro, Brasil.
} 


\section{Background}

There is a worldwide trend of women in the contemporary world delaying pregnancy, and such a change may impact both maternal and perinatal outcomes 1 . The etiology of adverse effects at birth is multifactorial and some outcomes, such as low birthweight $(<2,500 \mathrm{~g}) 2,3$, perinatal mortality 4 and abnormalities 5,6, show a connection with advanced maternal age. Also, maternal age and parity were shown to interact, whereby the impact of age at delivery differed between nulliparous and multiparous mothers 7,8 . Some studies have focused only on nulliparous women as a distinct population 2,4, however not only the mother's age at first childbirth is important to be analyzed as the risk factor of interest $8,9,10$, and are well documented in the literature relating to the subject.

However, other outcomes still require clarification, since existing studies either do not show the well-monitored confounding variables 8 , or they address new outcomes, such as neonatal near miss. Neonatal near miss is a term used to describe a newborn which suffered potentially fatal complications during the pregnancy period, childbirth, or in the first seven days after the termination of pregnancy 11 .

Repeated efforts attempted to establish the criteria for the neonatal near miss indicator $11,12,13,14,15,16,17,18,19$, however, there is not a standard global criteria. One of the criteria combines use of pragmatic and management markers of severity as predictors of early neonatal deaths using two World Health Organization (WHO) surveys. The aim was to guide leaders and policymakers regarding the distribution of often scarce resources, in order to improve the quality of healthcare and reduce neonatal mortality, especially in developing countries 16 .

The neonatal death rate in Brazil has significantly decreased from 25 deaths/1,000 live births in 1990 to 9 deaths/1,000 live births in 2017, but is still far from the high income countries whose rates are approximately 3 deaths $/ 1,000$ live births 20 . To reach this level, factors that contribute to the death or near death of newborns must be identified. Following the identification of factors, it will be possible to control or improve treatment for these factors in healthcare for the mother and the newborn. Advanced maternal age stands out as a significant factor warranting investigation.

Consequently, the aim of this study is to determine whether advanced maternal age increases the chance of neonatal near miss, and to pinpoint which factors are associated with neonatal near miss, according to parity.

\section{Methods}

Data for this study were obtained from a national hospital-based survey of postpartum women and their newborns, Birth in Brazil, carried out from February 2011 to October 2012. The sample was selected in three stages. The first included hospitals with more than 500 births/year, which were stratified according to macro-regions of the country (North, South, Northeast, Southeast and Central), location (capital or non-capital), and type of hospital (public, private, or both). In the second stage, the number of days required to interview 90 postnatal women in each of the 266 previously selected hospitals (minimum of 7 days) was defined using the inverse sampling method. In the third stage, the postpartum women and their newborns were selected. Further information on sample design can be found in the study by Vasconcellos et al. 21.

We applied the complex sampling design for all statistical analysis. Each stratum of selection was attributed a calibration procedure based on basic sample weights to ensure that the distribution of postpartum women was similar to that observed in births of the population sampled in 2011, deriving weighted percentages.

In this analysis, we considered all newborns of postpartum women between 20-29 years of age and 35 years of age or more. We chose these age ranges based on the Brazilian neonatal death rate that exceeds the level of 7/1,000 live births, which begins to increase at a faster rate for women aged 35 years or more (Departamento de Informática do SUS. Sistema de Informações sobre Nascidos Vivos. http://tabnet.datasus.gov.br/cgi/tabcgi.exe?sinasc/cnv/nvuf.def, accessed on 28/Feb/2016). The age group of 20 to 29 is considered the most adequate period for reproduction and delivery, since women have the lowest rates of chronic medical complications and pregnancy-induced complications 22,23. 
We did not include stillbirths and early neonatal deaths and their mothers, as to be a near miss the baby must have survived the first seven days of life. We collected information via interview with the postpartum women during their hospital stay by way of an electronic questionnaire. We recorded data from the prenatal card (via photographs), and maternal and newborn records, which we collected after the woman's discharge or on the 42nd day of hospital admission and/or after discharge from hospital or the 28th day of the newborn's hospitalization. Further details on data collection methods are described by Carmo Leal et al. 24 .

We established the neonatal near miss variable using recommendations from Pileggi-Castro et al. 16, which looked at two surveys carried out by the WHO. The existence of any of the following characteristics was used to indicate a neonatal near miss: pragmatic criteria: Apgar score $<7$ at $5^{\text {th }}$ minutes, birthweight $<1,750 \mathrm{~g}$ and gestational age $<33$ weeks; management criteria: use of antibiotics, continuous positive airway pressure (CPAP), phototherapy in the first 72 hours, vasoactive drug, anticonvulsants, surfactant, cardiac massage, hypoglycemia and orotracheal intubation.

We considered the following sociodemographic variables: maternal age (20-29 years, $\geq 35$ years), mother's years of schooling ( $<7$ years, 8-10 years, $>10$ years), classification of income level according to the Brazilian Association of Market Research Institutes (classes A/B - high income, C/D/E - lower income), race/color (white, black, brown, yellow and indigenous) and the region of residence (North, Northeast, Southeast, South and Central) and pre-gestational body mass index $\left(\mathrm{BMI}-\mathrm{kg} / \mathrm{m}^{2}\right)(<18.5=$ underweight, 18.5-24.9 = normal weight, 25.0-29.9 = overweight, 30.0 or more = obese) with imputation of about $17.5 \%$ of the missing data on weight and height using the chained equations method (MICE). The obstetric history involved: previous miscarriage, history of prematurity, history of low birthweight and previous C-section procedure, all of them classified as existing or non-existing. The variable related to prenatal healthcare was the minimum overall adequacy of prenatal care (minimally adequate, inadequate).

The minimum overall prenatal adequacy recommended by the Ministry of Health was adopted and adapted by Domingues et al. 25. Prenatal care was considered minimally adequate when: the onset of the care occurred up until the $12^{\text {th }}$ week of pregnancy; the number of consultations was adequate for gestational age at the time of delivery; at least one of the following routine exams was performed: syphilis serology, fasting blood sugar level, urine test, HIV serology and ultrasonography test; a maternal report regarding guidance to the reference hospital was performed.

We applied the following variables in this study: source of payment for childbirth (public or private), being turned away from hospital at the moment of childbirth - failure to be admitted to the first maternity ward sought for childbirth (yes or no), type of childbirth (vaginal, C-section with labor, C-section without labor, or vaginal forceps delivery) and maternal near miss (yes or no). Pregestational diseases included: pre-gestational diabetes, heart disease and chronic kidney disease. Complications of pregnancy included: hypertensive disease (chronic hypertension, pre-eclampsia, eclampsia or HELLP syndrome), prepartum and intrapartum hemorrhage, gestational diabetes and urinary infection, all classified either as existing or non-existing. Multiple gestations were also considered (no - one fetus or yes - more than one fetus), if any. We classified the maternal near miss according to clinical, laboratorial and management criteria defined by the WHO 26.

We performed all the analyses stratified by parity, because the literature shows that there is difference for some complications between the groups. We considered women who had not previously given birth as nulliparous and those who had given birth on one or more occasions as multiparous.

Initially, we verified each of the items that make up the near miss neonatal and the final indicator associated with age $\geq 35$ years. We also verified the socioeconomic characteristics of prenatal care, childbirth, pre-gestational diseases and obstetric history associated with neonatal near miss. For both analyses, the chi-square test was used to determine differences between proportions, considering a 95\% confidence interval (95\%CI).

We subsequently applied univariate and multiple logistic regression models to determine the characteristics of the neonatal near miss. The multivariable analysis was based on the hierarchical model, composed of distal (sociodemographic characteristics), intermediate (obstetrics pre-conditions and characteristics of health system) and proximal factors (pre-gestational diseases and pregnancy complications). Initially, each block of variables from a given level was included in the hierarchical analysis model, keeping all variables with $\mathrm{p}$-value $\leq 0.10$. In this model, the variables, located at a hierarchically 
higher level than that of the variable in question were considered as potential confounding in relation to the outcome, while variables located at lower levels were considered as potential mediators. Only the variables with $\mathrm{p}<0.05$ remained in the final model (adjusted OR).

We also calculated the near miss neonatal rate per 1,000 births according to maternal age. The rate for each maternal age is represented by the running average of the neonatal near miss divided by the total number of newborns. The mean is calculated using data from age analysis plus the age given before and afterwards. We used this feature to reduce random fluctuations, since the number of cases was small. For newborns with mothers over 42 years of age, the number of infants was considerably lower. For this reason, we grouped newborns of women aged $\geq 43$ years.

This research was approved by the Research Ethics Committee of the National School of Public Health of the Oswaldo Cruz Foundation, under n. 92/2010 and 2.041.963/2017 (CAAE: 63785517.2.0000.5240). We obtained consent from the directors of the hospitals, and from each postpartum woman who read and signed the informed consent form before the interview.

\section{Results}

A total of 15,092 newborns were included in this study; 6,219 (41.2\%) children of nulliparous women $-5,703$ (37.8\%) of mothers between 20-29 years of age, 516 (3.4\%) of mothers aged 35 years and over - and 8,873 (58.8\%) children of multiparous women - 6,868 (45.5\%) were of mothers between 20-29 years of age and 2,005 (13.3\%) of mothers of 35 years and over. Among the factors that make up the neonatal near miss indicator, we found a higher frequency of use of nasal CPAP, antibiotics, surfactant, phototherapy and hypoglycemia in newborns of women of advanced maternal age, regardless of parity. We also found higher frequency of weight $<1,750 \mathrm{~g}$ among nulliparous women, and gestational age $<33$ weeks in multiparous women (Table 1 ).

The average neonatal near miss rate was 91.7/1,000 births. In addition, the weighted arithmetic mean of neonatal near miss per 1,000 births according to the maternal age of patients aged 20-29 and older than 35 or more is illustrated in Figure 1. The trend showed an increase in the mean of neonatal

Table 1

Factors of neonatal near miss according to maternal age and parity. Brazil, 2011-2012.

\begin{tabular}{|c|c|c|c|c|c|c|}
\hline \multirow[t]{2}{*}{ Variables } & \multicolumn{3}{|c|}{ Nulliparous } & \multicolumn{3}{|c|}{ Multiparous } \\
\hline & $\begin{array}{c}20-29 \text { years old } \\
{[n=5,703]} \\
n(\%)\end{array}$ & $\begin{array}{c}\geq 35 \text { years old } \\
{[n=516]} \\
n(\%)\end{array}$ & p-value & $\begin{array}{c}20-29 \text { years old } \\
{[n=6,868]} \\
n(\%)\end{array}$ & $\begin{array}{c}\geq 35 \text { years old } \\
{[n=2,005]} \\
n(\%)\end{array}$ & p-value \\
\hline \multicolumn{7}{|l|}{ Neonatal near miss } \\
\hline Apgar $<7$ in the 5 th minute & $33(0.6)$ & $08(1.5)$ & 0.998 & $48(0.7)$ & $16(0.8)$ & 0.742 \\
\hline Weight $<1,750 \mathrm{~g}$ & $99(1.7)$ & $20(3.9)$ & 0.014 & $81(1.2)$ & $37(1.8)$ & 0.109 \\
\hline Gestational age $<33$ weeks & $135(2.4)$ & $20(3.9)$ & 0.109 & $123(1.8)$ & $70(3.5)$ & 0.002 \\
\hline Vasoactive drugs & $39(0.7)$ & $05(1.0)$ & 0.594 & $46(0.7)$ & $15(0.7)$ & 0.743 \\
\hline CPAP nasal & $173(3.0)$ & $21(4.1)$ & 0.001 & $128(1.9)$ & $61(3.1)$ & 0.008 \\
\hline Antibiotics & $261(4.5)$ & $47(9.0)$ & 0.003 & $245(3.6)$ & $88(4.4)$ & 0.005 \\
\hline Intubation & $80(1.4)$ & $08(1.6)$ & 0.783 & $74(1.1)$ & $32(1.6)$ & 0.104 \\
\hline Phototherapy & $268(4.7)$ & $62(12.1)$ & $<0.001$ & $206(3.0)$ & $115(5.8)$ & $<0.001$ \\
\hline Cardiac massage & $22(0.4)$ & $02(0.4)$ & 0.782 & $37(0.5)$ & $09(0.4)$ & 0.681 \\
\hline Anticonvulsant & $17(0.3)$ & $0(0)$ & - & $23(0.3)$ & $08(0.4)$ & 0.004 \\
\hline Surfactant & $78(1.4)$ & $18(3.5)$ & 0.002 & $75(1.1)$ & $45(2.3)$ & 0.006 \\
\hline Hypoglycemia & $74(1.3)$ & $10(2.0)$ & 0.003 & $44(0.6)$ & $42(2.1)$ & $<0.001$ \\
\hline \multicolumn{7}{|l|}{ Neonatal near miss indicator } \\
\hline No & $5,137(90.1)$ & $429(83.1)$ & 0.007 & $6,372(92.8)$ & $1,769(88.2)$ & $<0.001$ \\
\hline Yes & $566(9.9)$ & $87(16.9)$ & & $496(7.2)$ & $236(11.8)$ & \\
\hline
\end{tabular}


near misses as mothers got older; whilst the mean for younger women fluctuated around 80.0/1,000, in women of advanced maternal age it varied from $93.8 / 1,000$ to $157.8 / 1,000$.

The percentages of neonatal near miss and their associated factors are shown in Tables 2 and 3. Regardless of parity, we found the highest percentages of neonatal near miss with statistically significant differences in: maternal age $\geq 35$, existence of maternal near miss, presence of hypertensive disease, urine infection, and chronic kidney disease, and in cases of multiple gestation (p-value $<5 \%$ ). For nulliparous women, in addition to these factors, we observed higher percentages in women with pre-gestational BMI > 25.0 (overweight or obese), pre-existing conditions of heart disease, and pregestational diabetes. As for multiparous women, the highest percentages were for those who had $\leq 7$ years of schooling, who had a history of low birth weight and prematurity, who tried and failed to be admitted to the first hospital for the childbirth, who had a cesarean section or forceps delivery, and who suffered a prepartum and/or intrapartum haemorrhage.

Regardless of the parity, after adjustment by applying the variables of the final model, we found neonatal near miss increase in relation to the following factors: maternal age $\geq 35$ years, failure to be admitted at the maternity ward sought for childbirth, hypertensive disease, urine infection and multiple gestation. As for newborns from multiparous women, we also found that mother's years of schooling of $\leq 7$ years, type of delivery (cesarean birth without labor and forceps-assisted vaginal delivery), prepartum and/or intrapartum hemorrhage, pre-gestational chronic kidney disease, and a history of prematurity in previous pregnancies were variables related to the outcome (Table 4).

The chance of neonatal near miss for nulliparous women aged $\geq 35$ was $62 \%$ higher when compared to women aged 20-29, and for multiparous women this chance was $51 \%$ higher. In addition, the highest degree of association for neonatal near miss occurred in multiple gestations among nulliparous women, and forceps-assisted vaginal delivery among multiparous women, with probabilities eight and seven times higher, respectively, when compared to single pregnancies and vaginal delivery (Table 4).

\section{Figure 1}

Neonatal near miss rate per 1,000 live births according to maternal age at childbirth for women 20-29 years old and 35 years old or older.

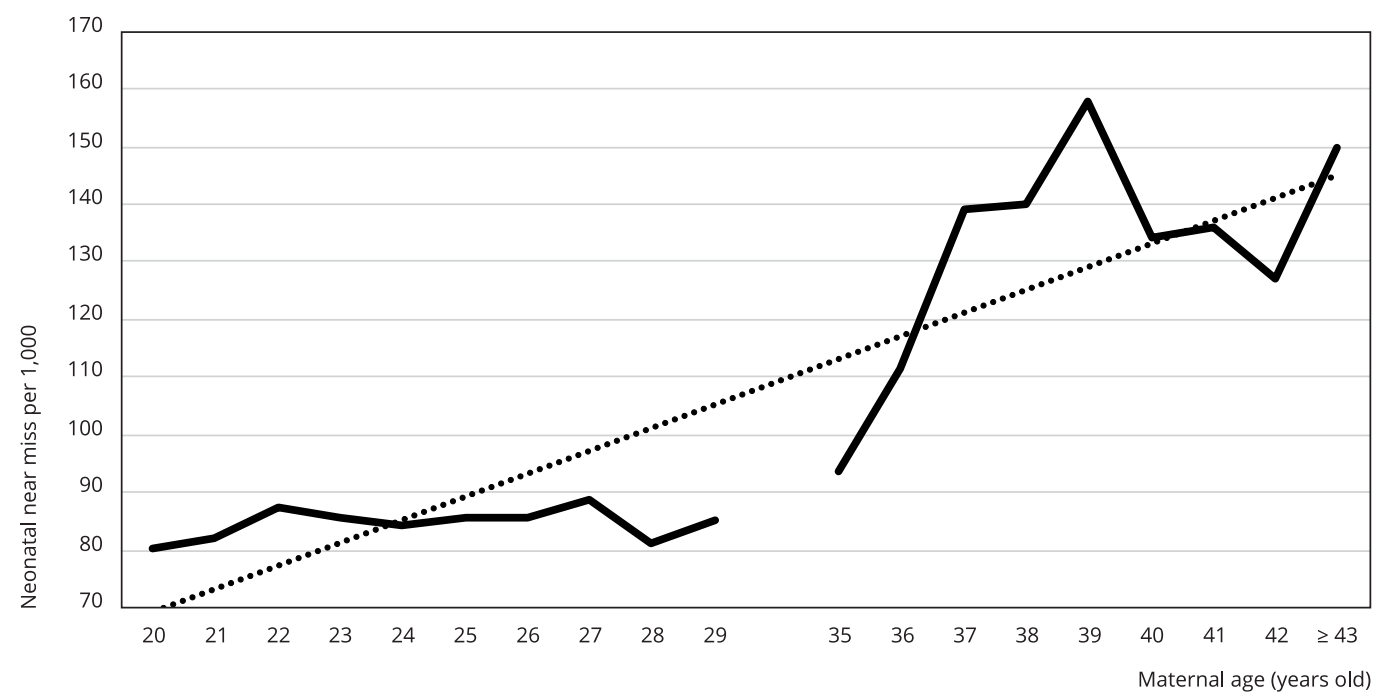

Notes: the continuous line represents the near miss neonatal rate smoothed by moving averages. The dashed line represents the expected values of a linear regression $(y=65.433+3.977 x)$. 
Table 2

Neonatal near miss according to sociodemographic characteristics ande obstetrics pre-conditions per parity. Brazil, 2011-2012.

\begin{tabular}{|c|c|c|c|c|c|c|}
\hline \multirow[t]{3}{*}{ Variables } & \multicolumn{6}{|c|}{ Neonatal near miss } \\
\hline & \multicolumn{3}{|c|}{ Nulliparous } & \multicolumn{3}{|c|}{ Multiparous } \\
\hline & Total (n) & Yes [n (\%)] & $\begin{array}{c}\chi^{2} \\
p \text {-value }\end{array}$ & Total (n) & Yes [n (\%)] & $\begin{array}{c}\chi^{2} \\
\text { p-value }\end{array}$ \\
\hline Maternal age (years) & & & 0.014 & & & $<0.001$ \\
\hline $20-29$ & 5,703 & $566(9.9)$ & & 6,868 & $496(7.2)$ & \\
\hline$\geq 35$ & 516 & 87 (16.9) & & 2,005 & $236(11.8)$ & \\
\hline Mother's years of schooling (years) & & & 0.669 & & & 0.027 \\
\hline$\leq 7$ & 578 & $64(11.1)$ & & 2,950 & $289(9.8)$ & \\
\hline $8-10$ & 1,014 & $109(10.7)$ & & 2,460 & $174(7.1)$ & \\
\hline$\geq 11$ & 4,598 & $475(10.3)$ & & 3,422 & $267(7.8)$ & \\
\hline Socioeconomic class & & & 0.995 & & & 0.231 \\
\hline Class D/E & 959 & $101(10.5)$ & & 2,398 & $235(9.8)$ & \\
\hline Class C & 3,319 & $338(10.2)$ & & 4,541 & $334(7.4)$ & \\
\hline Class A/B & 1,893 & $203(10.7)$ & & 1,853 & $154(8.3)$ & \\
\hline Skin color & & & 0.774 & & & 0.874 \\
\hline White & 2,381 & $245(10.3)$ & & 2,761 & $244(8.8)$ & \\
\hline Black & 482 & $51(10.6)$ & & 816 & $73(8.9)$ & \\
\hline Brown & 3,260 & $350(10.7)$ & & 5,171 & 407 (7.9) & \\
\hline Yellow & 75 & $5(6.7)$ & & 85 & $7(8.2)$ & \\
\hline Indigenous & 19 & $1(5.3)$ & & 39 & $2(5.1)$ & \\
\hline Region & & & 0.581 & & & 0.666 \\
\hline North & 420 & $41(9.8)$ & & 926 & $85(9.2)$ & \\
\hline Northeast & 1,909 & $229(12.0)$ & & 2,423 & $179(7.4)$ & \\
\hline Southeast & 2,726 & $283(10.4)$ & & 3,761 & $336(8.9)$ & \\
\hline South & 788 & $68(8.6)$ & & 1,141 & $90(7.9)$ & \\
\hline Central & 375 & $32(8.5)$ & & 622 & $43(6.9)$ & \\
\hline BMI pre-gestational $\left(\mathrm{kg} / \mathrm{m}^{2}\right)$ & & & 0.020 & & & 0.669 \\
\hline Below weight & 546 & $36(6.6)$ & & 569 & $48(8.4)$ & \\
\hline Normal & 3,956 & $400(10.1)$ & & 4,950 & $395(8.0)$ & \\
\hline Overweight & 1,229 & $152(12.4)$ & & 2,392 & $200(8.4)$ & \\
\hline Obesity & 488 & 65 (13.3) & & 963 & $89(9.2)$ & \\
\hline Previous abortion & & & 0.177 & & & 0.067 \\
\hline No & 5,470 & $546(10.0)$ & & 6,739 & $529(7.8)$ & \\
\hline Yes & 748 & $106(14.2)$ & & 2,133 & $203(9.3)$ & \\
\hline Low weight history & & & & & & $<0.001$ \\
\hline No & - & - & - & 7,791 & $588(7.5)$ & \\
\hline Yes & - & - & - & 923 & $126(13.7)$ & \\
\hline Prematurity history & & & & & & $<0.001$ \\
\hline No & - & - & - & 7,795 & $556(7.1)$ & \\
\hline Yes & - & - & - & 1,017 & $173(17.0)$ & \\
\hline Previous C-section & & & & & & 0.056 \\
\hline No & - & - & - & 5,332 & $398(7.5)$ & \\
\hline Yes & - & - & - & 3,485 & 329 (9.4) & \\
\hline
\end{tabular}

BMI: body mass index; C-section: cesarean section. 
Table 3

Near miss neonatal according to characteristics of prenatal care, childbirth and pre-gestational diseases and pregnancy complications per parity. Brazil, 2011-2012.

\begin{tabular}{|c|c|c|c|c|c|c|}
\hline \multirow[t]{3}{*}{ Variables } & \multicolumn{6}{|c|}{ Neonatal near miss } \\
\hline & \multicolumn{3}{|c|}{ Nulliparous } & \multicolumn{3}{|c|}{ Multiparous } \\
\hline & Total (n) & Yes [n (\%)] & p-value & Total (n) & Yes [n (\%)] & p-value \\
\hline Adequacy prenatal & & & 0.543 & & & 0.547 \\
\hline Inadequate & 4,982 & $534(10.7)$ & & 7,716 & $643(8.3)$ & \\
\hline Adequate & 1,235 & $118(9.6)$ & & 1,156 & $89(7.7)$ & \\
\hline Source of payment for childbirth & & & 0.863 & & & 0.935 \\
\hline Public & 4,440 & $462(10.4)$ & & 7,526 & $622(8.3)$ & \\
\hline Private & 1,778 & $190(10.7)$ & & 1,347 & $110(8.2)$ & \\
\hline Failing to be admitted at the first maternity ward sought for childbirth & & & 0.075 & & & 0.007 \\
\hline No & 5,003 & $503(10.1)$ & & 7,185 & $534(7.4)$ & \\
\hline Yes & 1,211 & $147(12.1)$ & & 1,686 & $198(11.7)$ & \\
\hline Mode of birth & & & 0.085 & & & $<0.001$ \\
\hline Vaginal-induced & 2,243 & $194(8.6)$ & & 4,541 & $290(6.4)$ & \\
\hline Cesarean with labor & 600 & $60(10.0)$ & & 644 & $67(10.4)$ & \\
\hline Cesarean with no labor & 3,266 & $385(11.8)$ & & 3,586 & $343(9.6)$ & \\
\hline Forceps-induced & 109 & $14(12.8)$ & & 102 & $32(31.4)$ & \\
\hline Multiple gestation & & & $<0.001$ & & & $<0.001$ \\
\hline No & 6,045 & $571(9.4)$ & & 8,677 & $673(7.8)$ & \\
\hline Yes & 172 & $81(47.1)$ & & 195 & $59(30.3)$ & \\
\hline Maternal near miss & & & 0.002 & & & 0.001 \\
\hline No & 6,148 & $631(10.3)$ & & 8,795 & $717(8.2)$ & \\
\hline Yes & 69 & $21(30.4)$ & & 78 & $15(19.2)$ & \\
\hline Hypertensive disease * & & & $<0.001$ & & & $<0.001$ \\
\hline No & 5,369 & $478(8.9)$ & & 7,833 & $586(7.5)$ & \\
\hline Yes & 849 & $174(20.5)$ & & 1,040 & $146(14.0)$ & \\
\hline Diabetes during pregnancy & & & 0.083 & & & 0.091 \\
\hline No & 5,746 & $593(10.3)$ & & 8,063 & $649(8.0)$ & \\
\hline Yes & 473 & $60(12.7)$ & & 810 & $83(10.2)$ & \\
\hline Hemorrhage & & & 0.909 & & & $<0.001$ \\
\hline No & 5,843 & $609(10.4)$ & & 8,373 & $636(7.6)$ & \\
\hline Yes & 374 & $43(11.5)$ & & 500 & $96(19.2)$ & \\
\hline Urinary infection & & & 0.004 & & & 0.041 \\
\hline No & 5,407 & $538(10.0)$ & & 7,610 & $600(7.9)$ & \\
\hline Yes & 810 & $114(14.1)$ & & 1,263 & $132(10.5)$ & \\
\hline Pre-gestational diabetes & & & 0.028 & & & 0.062 \\
\hline No & 6,174 & $643(10.4)$ & & 8,743 & $714(8.2)$ & \\
\hline Yes & 43 & 9 (20.9) & & 130 & $18(13.8)$ & \\
\hline Cardiac disease & & & 0.011 & & & 0.383 \\
\hline No & 6,182 & $639(10.3)$ & & 8,808 & $725(8.2)$ & \\
\hline Yes & 36 & $13(36.1)$ & & 65 & $7(10.8)$ & \\
\hline Chronic kidney disease & & & 0.015 & & & 0.001 \\
\hline No & 6,208 & $648(10.4)$ & & 8,848 & $726(8.2)$ & \\
\hline Yes & 10 & $4(40.0)$ & & 25 & $6(24.0)$ & \\
\hline
\end{tabular}

* Chronic hypertension, pre-eclampsia, eclampsia or HELLP syndrome. 
Table 4

Factors related to neonatal near miss of nulliparous ande multiparous. Brazil, 2011-2012.

\begin{tabular}{|c|c|c|c|c|}
\hline \multirow[t]{2}{*}{ Variables } & \multicolumn{2}{|c|}{ Nulliparous } & \multicolumn{2}{|c|}{ Multiparous } \\
\hline & $\begin{array}{c}\mathrm{OR} * \\
(95 \% \mathrm{Cl})\end{array}$ & $\begin{array}{l}\text { Adjusted OR ** } \\
\qquad(95 \% \mathrm{Cl})\end{array}$ & $\begin{array}{c}\mathrm{OR} * \\
(95 \% \mathrm{Cl})\end{array}$ & $\begin{array}{l}\text { Adjusted OR ** } \\
\qquad(95 \% \mathrm{Cl})\end{array}$ \\
\hline \multicolumn{5}{|l|}{ Age (years) } \\
\hline $20-29$ & 1.00 & 1.00 & 1.00 & 1.00 \\
\hline$\geq 35$ & $1.83(1.18-2.85)$ & $1.62(1.05-2.50)$ & $1.71(1.35-2.17)$ & $1.51(1.20-1.91)$ \\
\hline \multicolumn{5}{|l|}{ BMI pre-gestational $\left(\mathrm{kg} / \mathrm{m}^{2}\right)$} \\
\hline Below weight & $0.63(0.39-0.99)$ & - & - & - \\
\hline Normal & 1.00 & - & - & - \\
\hline Overweight & $1.25(0.95-1.64)$ & - & - & - \\
\hline Obesity & $1.36(0.98-1.88)$ & - & - & - \\
\hline \multicolumn{5}{|c|}{ Mother's years of schooling (years) } \\
\hline$\leq 7$ & - & - & $1.43(1.09-1.87)$ & $1.34(1.04-1.74)$ \\
\hline $8-10$ & - & - & 1.00 & 1.00 \\
\hline$\geq 11$ & - & - & $1.11(0.88-1.40)$ & $1.05(0.83-1.34)$ \\
\hline \multicolumn{5}{|c|}{$\begin{array}{l}\text { Failing to be admitted at the first maternity ward sought for } \\
\text { childbirth }\end{array}$} \\
\hline No & 1.00 & 1.00 & 1.00 & 1.00 \\
\hline Yes & $1.24(0.90-1.70)$ & $1.43(1.08-1.89)$ & $1.66(1.17-2.34)$ & $1.58(1.19-2.11)$ \\
\hline \multicolumn{5}{|l|}{ Mode of birth } \\
\hline Vaginal-induced & 1.00 & & 1.00 & 1.00 \\
\hline Cesarean with labor & $1.16(0.82-1.65)$ & - & $1.71(1.23-2.38)$ & $1.41(0.99-2.00)$ \\
\hline Cesarean with no labor & $1.41(1.06-1.86)$ & & $1.55(1.27-1.90)$ & $1.51(1.19-1.91)$ \\
\hline Forceps-induced & $1.53(0.84-2.78)$ & - & $6.70(1.88-23.90)$ & $7.19(1.96-26.28)$ \\
\hline \multicolumn{5}{|l|}{ 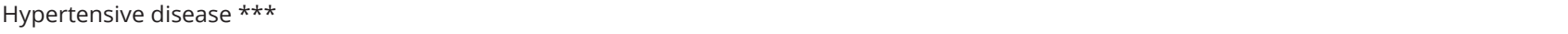 } \\
\hline No & 1.00 & 1.00 & 1.00 & 1.00 \\
\hline Yes & $2.64(2.08-3.34)$ & $2.57(2.04-3.24)$ & $2.02(1.63-2.50)$ & $1.49(1.19-1.86)$ \\
\hline \multicolumn{5}{|l|}{ Hemorrhage } \\
\hline No & - & - & 1.00 & 1.00 \\
\hline Yes & - & - & $2.89(2.02-4.13)$ & $2.77(1.98-3.87)$ \\
\hline \multicolumn{5}{|l|}{ Urinary infection } \\
\hline No & 1.00 & 1.00 & 1.00 & 1.00 \\
\hline Yes & $1.48(1.10-2.00)$ & $1.66(1.25-2.22)$ & $1.37(0.99-1.88)$ & $1.42(1.06-1.92)$ \\
\hline \multicolumn{5}{|l|}{ Multiple gestation } \\
\hline No & 1.00 & 1.00 & 1.00 & 1.00 \\
\hline Yes & $8.53(3.00-24.20)$ & $8.91(3.10-25.62)$ & $5.18(3.18-8.46)$ & $4.47(2.70-7.39)$ \\
\hline \multicolumn{5}{|l|}{ Pre-gestational diabetes } \\
\hline No & 1.00 & - & 1.00 & - \\
\hline Yes & $2.32(1.01-5.37)$ & - & $1.81(0.98-3.32)$ & - \\
\hline \multicolumn{5}{|l|}{ Chronic kidney disease } \\
\hline No & 1.00 & - & 1.00 & 1.00 \\
\hline Yes & $6.10(1.07-35.00)$ & - & $3.48(1.51-8.06)$ & $3.28(1.53-7.04)$ \\
\hline \multicolumn{5}{|l|}{ Prematurity history } \\
\hline No & - & - & 1.00 & 1.00 \\
\hline Yes & - & - & $2.62(1.95-3.52)$ & $2.53(1.91-3.34)$ \\
\hline \multicolumn{5}{|l|}{ Previous C-section } \\
\hline No & - & - & 1.00 & - \\
\hline Yes & - & - & $1.29(1.04-1.61)$ & - \\
\hline
\end{tabular}

95\% Cl: 95\% confidence interval; BMI: body mass index; C-section: cesarean section; OR: odds ratio.

* All variables were tested with $p$-value $<0.10$. However, only ones considered in the table where the ones tested according to the final model.

** OR adjusted by the variables that continued in the final model.

*** Hypertensive disease = chronic hypertension+pre-eclampsia+eclampsia or HELLP syndrome. 


\section{Discussion}

Advanced maternal age was shown to be a risk factor for neonatal near miss in nulliparous and multiparous women. Even after other confounding variables were controlled, the risk proved to be significantly higher in women aged 35 years and older. Factors related to access to healthcare services for childbirth, maternal characteristics and gestational complications also played an important role in the explanation of the neonatal near miss, although the determination of these factors was different among nulliparous and multiparous women.

The neonatal near miss rate for this study was higher than the figures found by Pillegi-Castro et al. 16 for Brazil, namely 71.8/1,000 births. However, the authors of the aforementioned study did not use a representative sample from Brazil. Women aged 30-34 were not included, which is likely to have reduced the neonatal near miss rate, since younger women showed lower rates. This indicator is considered high when compared to countries with a very high Human Development Index (HDI), which showed a mean rate of $39.0 / 1,000$ births 16 , and is considered low when compared to two maternity hospital for high-risk pregnancy in Brazil (147.3/1,000 births and 220/1,000 births) 13,27. This showed that the healthcare system needs to improve prenatal care and peripartum care for pregnant women and their newborns in order to minimize the number of births with adverse perinatal outcomes.

Negative perinatal outcomes such as prematurity, low birth weight and Apgar $<7$ in the 5 th minute are items that make up the neonatal near miss and also relate in the same way to maternal age, when it is presented continuously 8 . As in this study, the chance of neonatal near miss increases by more than $50 \%$ for mothers age $\geq 35$ years 7 .

A study carried out in China confirmed the relationship of prematurity with maternal age and cesarean section without labor. This study, even when adjusting the model for hypertensive disorders, diabetes mellitus and antepartum hemorrhage - factors also associated with prematurity - found a greater chance of premature birth in women of advanced maternal age 28. In addition, comparing preterm and spontaneous preterm delivery with regard to parity of younger women with those of advanced maternal age women, the study found a greater chance of preterm birth in multiparous women, but not in spontaneous preterm birth, indicating that older Chinese women have their deliveries induced by the provider 28 . The main causes of non-spontaneous birth before 34 weeks are pre-eclampsia and small for gestational age infants 29 , showing that the management and provision of antenatal care for advanced maternal age women show peculiar characteristics that should be closely observed 28 .

Cesarean section without labor and forceps-assisted delivery were also associated with neonatal near miss. This may reflect therapeutic interventions that attempt to provide better childbirth care in situations where vaginal delivery is not recommended 30 . This idea is reinforced by another study carried out in the same population, which found no connection between the different types of childbirth and neonatal mortality 31 . However, it is also possible that some cesarean sections were performed without medical indication in babies under 39 weeks, resulting clearly in more serious consequences, such as cardiorespiratory arrest, sepsis, phototherapy, admission into neonatal intensive care unit (ICU), hospitalization, and hypoglycemia 32 . In addition, need for hospital care during childhood, mainly due to obstructive airway diseases and ophthalmological and motor problems 33 .

Gestational complications, such as hypertensive diseases (pre-eclampsia and eclampsia), urine infection and pre and intra-partum hemorrhage turned out to be related to neonatal near miss. These are complications that make up the gestational risk and must be correctly diagnosed and properly treated in the prenatal period, so as to avoid negative outcomes for the woman and the fetus 34,35 . A study conducted by the WHO in 29 countries found that only $11.4 \%$ of early neonatal deaths were not associated with maternal complications 36 , suggesting that deaths could be prevented through a comprehensive approach by pregnant women, starting from early identification of risk pregnancies, treatment of infections and gestational complications in a timely manner, and referral to a hospital equipped with facilities capable of providing the mother and the newborn with adequate healthcare 31,34.

In addition to the characteristics described, in order to prevent neonatal deaths, it is essential to control intrauterine hypoxia, and to introduce good practices in labor and delivery, training multiprofessional teams to follow protocols based on scientific evidence and to provide qualified healthcare through a regionalized and hierarchical network. Late prematurity and intrapartum asphyxia 
were the main causes of preventable neonatal deaths in Brazil, and are preventable by the implementation of recommended practices in childbirth and delivery, once services are available 31 .

Practices such as triage and proper referral of pregnant women at risk, whose newborns may present complications during childbirth and in the first hours of life, are key in the prevention of deaths 36,37 , since many of them die due to lack of a neonatal ICU or transfer to a hospital with more complex resources 31 . Thus, when analyzing the neonatal near miss in infants considered small for gestational age, in countries of low HDI, $49 \%$ of neonates $<32$ gestational weeks experienced neonatal near miss, of which $70 \%$ died, while in countries with high HDI, where prenatal care is widely provided and delivery assistance is adequate, $80 \%$ of newborns with gestational age $<32$ weeks experienced neonatal near miss, and perinatal mortality rate amounted to approximately $11 \% 36$.

Another problem of perinatal care is the failure to be admitted to the maternity hospital sought for childbirth by pregnant woman with intercurrences, which may be a result of the lack of a referral to a hospital better equipped for childbirth or due to the woman's own difficulties 36 . The delay caused by pregnant woman searching for an adequate service can constitute one of the factors for the worsening of her condition and of the situation of the fetus, since in regions far from the capital city, delivery care is mostly provided by mixed private units, associated to the Brazilian Unified National Health System (SUS), generally without the infrastructure necessary to serve both pregnant woman and infants at risk in the Brazilian context 38 .

\section{Strengths and limitations}

This study is valuable in that it identifies factors related to neonatal near miss, regarding age and parity. Given the fact that little research has been conducted on the topic, most neonatal near miss studies focus on determining the criteria for this indicator, rather than on the factors associated with it. In addition, not only does this study use pragmatic criteria, it makes use of a representative sample in Brazil and stands out by applying the protocol proposed by WHO for the composition of the indicator.

Some limitations should be mentioned, such as the absence of blood transfusion variables and surgery up to seven days of life, which make up the 14 criteria described by WHO. The frequency, however, was extremely low in the study of the protocol ( $0.26 \%$ and $0.07 \%$, respectively) ${ }^{16}$. Moreover, these are more serious characteristics, and infants showing them were probably already accounted for by other characteristics making up the neonatal near miss.

Furthermore, this study does not include the variable conception by in vitro fertilization to analyze its relationship with neonatal near miss. Nonetheless, this is not very prevalent in Brazil, and since it is not part of the table of procedures covered by SUS, and is restricted to private clinics with very high costs, the chance of these women forming part of the study is low. Hence, the early neonatal death outcome was used as a proxy for the neonatal near miss during the discussion of this study, as studies have not yet analyzed the factors associated with this outcome.

\section{Conclusion}

Neonatal near miss has been shown to be connected with access to health services for childbirth, gestational complications and maternal characteristics, including advanced maternal age. Therefore, to properly monitor and classify maternal gestational risk, to control gestational complications during prenatal care, and to correctly refer these women to childbirth care should be priority strategies for healthcare services aiming to reduce neonatal near miss rates and mortality. In addition, women who wish to conceive should be advised of the greater risk of negative outcomes related to a late pregnancy, and of the care that can be taken to reduce such risks. 


\section{Contributors}

K. G. Martinelli contributed in the conception and project of the article; analysis and interpretation of data; writing of the article and relevant critical review of the intellectual content; and final approval of the version to be published. S. G. N. Gama and E. T. Santos Neto contributed in the conception and project of the article; relevant critical review of the intellectual content; and Final approval of the version to be published. A. H. V. Almeida contributed in the relevant critical review of the intellectual content; and final approval of the version to be published. V. E. Pacheco contributed in the analysis and interpretation of data; and final approval of the version to be published.

\section{Additional informations}

ORCID: Katrini Guidolini Martinelli (0000-00030894-3241); Silvana Granado Nogueira da Gama (0000-0002-9200-0387); André Henrique do Vale de Almeida (0000-0003-4949-2192); Vanessa Eufrauzino Pacheco (0000-0003-0111-2859); Edson Theodoro dos Santos Neto (0000-00027351-7719).

\section{References}

1. Laopaiboon M, Lumbiganon P, Intarut N, Mori R, Ganchimeg T, Vogel JP, et al. Advanced maternal age and pregnancy outcomes: a multicountry assessment. BJOG 2014; 121 Suppl 1:49-56.

2. Beydoun H, Itani M, Tamim H, Aaraj A, Khogali M, Yunis K. Impact of maternal age on preterm delivery and low birthjweight: a hospital-based collaborative study of nulliparous Lebanese women in Greater Beirut. J Perinatol 2004; 24:228-35.

3. Tabcharoen C, Pinjaroen S, Suwanrath C, Krisanapan O. Pregnancy outcome after age 40 and risk of low birthweight. J Obstet Gynaecol 2009; 29:378-83.

4. Joseph KS, Allen AC, Dodds L, Turner LA, Scott $\mathrm{H}$, Liston $\mathrm{R}$. The perinatal effects of delayed childbearing. Obstet Gynecol 2005; 105:1410-8.

5. Ciancimino L, Laganà $\mathrm{AS}$, Chiofalo $\mathrm{B}$, Granese $\mathrm{R}$, Grasso R, Triolo O. Would it be too late? A retrospective case-control analysis to evaluate maternal-fetal outcomes in advanced maternal age. Arch Gynecol Obstet 2014; 290:1109-14.

6. Grotegut CA, Chisholm CA, Johnson LN, Brown HL, Heine RP, James AH. Medical and obstetric complications among pregnant women aged 45 and older. PLoS One 2014; 9:e96237.

7. Kale PL, Mello-Jorge MHP, Silva KSD, Fonseca SC. Neonatal near miss and mortality: factors associated with life-threatening conditions in newborns at six public maternity hospitals in Southeast Brazil. Cad Saúde Pública 2017; 33:e00179115.

8. Weng YH, Yang CY, Chiu YW. Risk assessment of adverse birth outcomes in relation to maternal age. PLoS One 2014; 9:e114843.

9. Almeida NKO, Almeida RM, Pedreira CE. Adverse perinatal outcomes for advanced maternal age: a cross-sectional study of Brazilian births. J Pediatr (Rio J.) 2015; 91:493-8.

10. Başer E, Seçkin KD, Erkilinç S, Karsli MF, Yeral IM, Kaymak O, et al. The impact of parity on perinatal outcomes in pregnancies complicated by advanced maternal age. J Turk Ger Gynecol Assoc 2013; 14:205-9.

11. Pileggi C, Souza JP, Cecatti JG, Faúndes A. Neonatal near miss approach in the 2005 WHO Global Survey Brazil. J Pediatr (Rio J.) 2010; 86:21-6.

12. Avenant T. Neonatal near miss: a measure of the quality of obstetric care. Best Pract Res Clin Obstet Gynaecol 2009; 23:369-74.

13. França KEX, Vilela MBR, Frias PG, Gaspar GS, Sarinho SW. Near miss neonatal precoce identificado com base em sistemas de informação em saúde. Cad Saúde Pública 2018; 34:e00167717.

14. Manandhar SR, Manandhar DS, Adhikari D, Shrestha JR, Rai C, Rana H, et al. Neonatal near miss cases of different health facilities. J Nepal Paediatr Soc 2014; 34:115-8. 
15. Nakimuli A, Mbalinda SN, Nabirye RC, Kakaire O, Nakubulwa S, Osinde MO, et al. Still births, neonatal deaths and neonatal near miss cases attributable to severe obstetric complications: a prospective cohort study in two referral hospitals in Uganda. BMC Pediatr 2015; 15:44.

16. Pileggi-Castro C, Camelo Jr. J, Perdoná G, Mussi-Pinhata MM, Cecatti JG, Mori R, et al. Development of criteria for identifying neonatal nearmiss cases: analysis of two WHO multicountry cross-sectional studies. BJOG 2014; 121 Suppl 1:110-8.

17. Ronsmans C, Cresswell JA, Goufodji S, Goufodji S, Agbla S, Ganaba R, et al. Characteristics of neonatal near miss in hospitals in Benin, Burkina Faso and Morocco in 2012-2013. Trop Med Int Health 2016; 21:535-45.

18. Santos JP, Pileggi-Castro C, Camelo JS, Silva AA, Duran P, Serruya SJ, et al. Neonatal near miss: a systematic review. BMC Pregnancy Childbirth 2015; 15:320.

19. Silva AAM, Leite AJM, Lamy ZC, Moreira MEL, Gurgel RQ, Cunha AJLA, et al. Morbidade neonatal near miss na pesquisa Nascer no Brasil. Cad Saúde Pública 2014; 30 Suppl 1:S182-91.

20. United Nations Children's Fund; World Health Organization; World Bank Group; United Nations. Levels \& trends in child mortality: report 2017. New York: United Nations Children's Fund; 2017.

21. Vasconcellos MTL, Silva PLN, Pereira APE, Schilithz AOC, Souza Junior PRB, Szwarcwald CL. Desenho da amostra Nascer no Brasil: Pesquisa Nacional sobre Parto e Nascimento. Cad Saúde Pública 2014; 30 Suppl 1:S49-58.

22. Canhaço EE, Bergamo AM, Lippi UG, Lopes RGC. Perinatal outcomes in women over 40 years of age compared to those of other gestations. Einstein (São Paulo) 2015; 13:58-64.

23. Liu X, Zhang W. Effect of maternal age on pregnancy: a retrospective cohort study. Chin Med J (Engl) 2014; 127:2241-6.

24. Carmo Leal M, da Silva AA, Dias MA, da Gama SG, Rattner D, Moreira ME, et al. Birth in Brazil: national survey into labour and birth. Reprod Health 2012; 9:15.

25. Domingues RMSM, Viellas EF, Dias MAB, Torres JA, Theme-Filha MM, Gama SG, et al. Adequação da assistência pré-natal segundo as características maternas no Brasil. Rev Panam Salud Pública 2015; 37:140-7.

26. Souza JP, Gülmezoglu AM, Carroli G, Lumbiganon P, Qureshi Z; WHOMCS Research Group. The World Health Organization multicountry survey on maternal and newborn health: study protocol. BMC Health Serv Res 2011; 11:286.

27. Lima THB, Katz L, Kassar SB, Amorim MM. Neonatal near miss determinants at a maternity hospital for high-risk pregnancy in Northeastern Brazil: a prospective study. BMC Pregnancy Childbirth 2018; 18:401.
28. Chan BC, Lao TT. Effect of parity and advanced maternal age on obstetric outcome. Int J Gynaecol Obstet 2008; 102:237-41.

29. McKinney D, Boyd H, Langager A, Oswald M, Pfister A, Warshak CR. The impact of fetal growth restriction on latency in the setting of expectant management of preeclampsia. Am J Obstet Gynecol 2016; 214:395.

30. Silva GA, Rosa KA, Saguier ESF, Henning E, Mucha F, Franco SC. A populational based study on the prevalence of neonatal near miss in a city located in the South of Brazil: prevalence and associated factors. Rev Bras Saúde Matern Intant 2017; 17:159-67.

31. Lansky S, Friche AAL, Silva AAM, Campos D, Bittencourt SDA, Carvalho ML, et al. Pesquisa Nascer no Brasil: perfil da mortalidade neonatal e avaliação da assistência à gestante e ao recém-nascido. Cad Saúde Pública 2014; 30 Suppl 1:S192-207.

32. Leal MDC, Esteves-Pereira AP, NakamuraPereira M, Domingues RMSM, Dias MAB, Moreira ME, et al. Burden of early-term birth on adverse infant outcomes: a populationbased cohort study in Brazil. BMJ Open 2017; 7:e017789.

33. Delnord M, Zeitlin J. Epidemiology of late preterm and early term births - an international perspective. Semin Fetal Neonatal Med 2019; 24:3-10.

34. Vogel J, Souza J, Mori R, Morisaki N, Lumbiganon P, Laopaiboon M, et al. Maternal complications and perinatal mortality: findings of the World Health Organization Multicountry Survey on Maternal and Newborn Health. BJOG 2014; 121:76-88.

35. Khanam R, Ahmed S, Creanga AA, Begum N, Koffi AK, Mahmud A, et al. Antepartum complications and perinatal mortality in rural Bangladesh. BMC Pregnancy Childbirth 2017; 17:81.

36. Ota E, Ganchimeg T, Morisaki N, Vogel JP, Pileggi C, Ortiz-Panozo E, et al. Risk factors and adverse perinatal outcomes among term and preterm infants born small-for-gestational-age: secondary analyses of the WHO Multi-Country Survey on maternal and newborn health. PLoS One 2014; 9:e105155.

37. Shroff BD, Ninama NH. A call for eminence obstetrics care by way of "Neonatal Near Miss" events (NNM): a hospital-based case-control study. J Obstet Gynaecol India 2019; 69:50-5.

38. Bittencourt SDA, Reis LGC, Ramos MM, Rattner D, Rodrigues PL, Neves DCO, et al. Estrutura das maternidades: aspectos relevantes para a qualidade da atenção ao parto e nascimento. Cad Saúde Pública 2014; 30 Suppl 1:S208-19. 


\section{Resumo}

O período neonatal precoce representa cerca da metade dos óbitos em crianças com menos de um ano de idade, e o near miss neonatal é capaz de identificar os fatores responsáveis por esse número elevado de mortes. Portanto, o estudo procurou investigar se a idade materna avançada aumenta a probabilidade de near miss neonatal, além de identificar os fatores associados ao near miss neonatal, estratificados por paridade. Os dados foram obtidos do estudo Nascer no Brasil de 2011-2012, que usou uma amostra representativa da população nacional com 15.092 recém-nascidos de mães com 20-29 anos de idade e com 35 anos ou mais (idade materna avançada). Foi usado um modelo de regressão logística multivariada para testar a associação entre near miss neonatal e variáveis do pré-natal e do parto, doenças pré-gestacionais, história obstétrica e características socioeconômicas, estratificadas por paridade. A idade materna avançada mostrou estar associada estatisticamente com o near miss neonatal em mulheres nulíparas $(O R=1,62$; IC95\%: 1,05-2,50) e multiparas $(O R=$ 1,51; IC95\%: 1,20-1,91) comparado com mulheres com 20-29 anos de idade. Entre as mulheres nuliparas, as principais variáveis associadas estatisticamente com o near miss neonatal foram a gestação múltipla $(O R=8,91)$ e doença hipertensiva $(O R=2,57)$, enquanto o parto vaginal com uso de fórceps $(O R=7,19)$ e gestação múltipla $(O R=$ $4,47)$ foram as variáveis associadas em mulheres multiparas. $O$ near miss neonatal mostrou estar relacionado ao acesso aos serviços obstétricos, complicações gestacionais e características maternas, principalmente idade materna avançada. Portanto, monitorar e classificar adequadamente o risco gestacional, controlar as complicações gestacionais durante o atendimento pré-natal e encaminhar essas mulheres corretamente para o atendimento no parto devem ser estratégias prioritárias para os serviços de saúde.

Mortalidade Neonatal Precoce; Idade Materna; Near Miss; Cuidado Pré-Natal

\section{Resumen}

El periodo neonatal temprano cuenta con aproximadamente la mitad de muertes de niños pequeños con una edad inferior a un año, y la near miss neonatal puede identificar factores que causan este número elevado de muertes. Por ello, el objetivo de este estudio es determinar si una edad avanzada maternal incrementa la oportunidad de near miss neonatal, además de identificar qué factores están asociados con la near miss neonatal, estratificada por paridad. Los datos son del 2011-2012, procedentes del estudio Nacer en Brasil, que utilizó una muestra nacional basada en población, compuesta por 15.092 recién nacidos de mujeres entre 20-29 y 35 años de edad o más (edad avanzada maternal). Se realizó una regresión múltiple logística para probar la asociación entre near miss neonatal y las variables prenatales, $y$ de nacimiento de niños, enfermedades pregestacionales, historial obstétrico y características socioeconómicas, estratificada por paridad. La edad avanzada maternal estuvo estadísticamente asociada con near miss neonatal en nuliparas $(O R=1,62$; 95\%CI: 1,052,50) y multiparas $(O R=1,51$; 95\%CI: 1,20-1,91), cuando se compara con mujeres de 20-29 años de edad. Para las mujeres nulíparas, las principales variables estadisticamente asociadas con near miss neonatal fueron múltiple gestación $(O R=$ $8,91)$ y enfermedad hipertensiva $(O R=2,57)$, mientras que el parto vaginal con apoyo de fórceps $(O R=7,19)$ y la gestación múltiple $(O R=4,47)$ fueron las variables asociadas para mujeres multíparas. Near miss neonatal ha demostrado estar relacionada con el acceso a servicios de salud para el parto, complicaciones gestacionales y características maternas, principalmente edad avanzada maternal. Por consiguiente, debería ser una estrategia prioritaria en los servicios de salud supervisar adecuadamente y clasificar el riesgo maternal gestacional, así como las complicaciones en el control gestacional durante el cuidado prenatal, al igual que dirigir correctamente a estas mujeres a cuidados para el parto.

Mortalidad Neonatal Precoz; Edad Materna; Near Miss Salud; Atención Prenatal
Submitted on $26 /$ Sep/2018

Final version resubmitted on 25/Apr/2019

Approved on 28/May/2019 